\title{
Study of immune reconstitution inflammatory syndrome during antiretroviral therapy in South Indian HIV patients
}

\author{
A Pramod Kumar ${ }^{1 *}$, G Parthasarathi ${ }^{1}$, SN Mothi ${ }^{2}$, VHT Swamy ${ }^{2}$, AP Sudheer ${ }^{3}$, S Rajendra Prasad ${ }^{3}$ \\ From 2nd International Science Symposium on HIV and Infectious Diseases (HIV SCIENCE 2014) \\ Chennai, India. 30 January - 1 February 2014
}

\section{Background}

Immune reconstitution inflammatory syndrome (IRIS) is a common cause of death and even more common cause of morbidity in patients started on highly active antiretroviral therapy (HAART). At present, very limited data is available about IRIS in the local population so the present study was conducted to determine the incidence, clinical manifestations, risk factors and outcomes of IRIS in south Indian HIV/AIDS patients.

\section{Methods}

Study was a prospective surveillance method to identify IRIS from two ART centers in Mysore city, India for a period of two years. HIV patients who are initiated with HAART were included for the study and were followed up for a period of six months. Data were analyzed using SPSS version 21 .

\section{Results}

Out of 798 people followed 82 patients had experienced IRIS with an incidence rate of $10 \%$. Among them $48 \%$ were unmasking and rest were paradoxical worsening. Diagnosis included tuberculosis (44\%), herpes zoster (18\%), cryptococcal meningitis (11\%) and other opportunistic infections (27\%). The major manifestation of IRIS were fever (44\%) followed by lymphadenitis (36\%). Statistically important predictors for occurrence of IRIS were male gender and low CD4 count. Two deaths were attributable to IRIS and $54 \%$ of them required hospitalization.

\footnotetext{
* Correspondence: pramod_pharmacist@yahoo.com

'JSS College of Pharmacy, Department of Clinical Pharmacy, JSS University, Mysore, India

Full list of author information is available at the end of the article
}

\section{Conclusion}

Patients with advanced immunodeficiency at HAART initiation are at greatest risk of developing IRIS and should be appropriately screened and monitored. Educational programs on recognizing and treating these conditions should be initiated in ART access programs.

\section{Authors' details}

'JSS College of Pharmacy, Department of Clinical Pharmacy, JSS University, Mysore, India. ${ }^{2}$ Asha kirana Hospital; Center for AIDS care and Research, Mysore, India. ${ }^{3}$ Vivekananda Memorial Hospital, Saragur, Mysore, India.

Published: 27 May 2014

doi:10.1186/1471-2334-14-S3-P53

Cite this article as: Kumar et al:: Study of immune reconstitution inflammatory syndrome during antiretroviral therapy in South Indian HIV patients. BMC Infectious Diseases 2014 14(Suppl 3):P53.
Submit your next manuscript to BioMed Central and take full advantage of:

- Convenient online submission

- Thorough peer review

- No space constraints or color figure charges

- Immediate publication on acceptance

- Inclusion in PubMed, CAS, Scopus and Google Scholar

- Research which is freely available for redistribution
() Biomed Central 